\title{
Memanfaatkan Algoritma K-Means Dalam Memetakan Potensi Hasil Produksi Kelapa Sawit PTPN IV Marihat
}

\author{
Deny Franata Pasaribu' ${ }^{1}$, Irfan Sudahri Damanik ${ }^{2}$, Eka Irawan ${ }^{3}$, Suhada $^{3}$, Heru Satria Tambunan ${ }^{5}$ \\ 1,2,3,4,5 Jurusan Sistem Informasi, STIKOM Tunas Bangsa Pematangsiantar \\ 11denyfranata2016@gmail.com, 2irfansudahri@amiktunasbangsa.ac.id, ${ }^{3}$ eka.irawan@ amiktunasbangsa.ac.id, \\ ${ }^{1}$ suhada.atb@gmail.com, ${ }^{1}$ heru@amiktunasbangsa.ac.id
}

\begin{tabular}{|c|c|}
\hline Keywords: & ABSTRACT \\
\hline $\begin{array}{l}\text { Grouping, } \\
\text { Data Mining, } \\
\text { Cluster, } \\
\text { K-Means Algorithm, } \\
\text { Palm, }\end{array}$ & $\begin{array}{l}\text { Based on data on the results of oil palm production in PTPN IV Marihat } \\
\text { displays several locations with fruit yields that vary in number. For this } \\
\text { reason, grouping of potential fruit-producing locations is needed to know } \\
\text { which locations produce large or small numbers of palm fruit. The production } \\
\text { sharing is usually done based on the location or block of harvesting oil palm } \\
\text { fruit. Therefore, a method is needed to facilitate the grouping of fruit } \\
\text { producing locations. With the K-Means clustering approach, the division of } \\
\text { location groups can be done based on harvested area (Ha), production } \\
\text { realization (kg) and harvest year. In this research, clustering of potential fruit- } \\
\text { producing areas was carried out using the K-Means algorithm. By using K- } \\
\text { Means aims to facilitate the grouping of a block with a lot of fruit production, } \\
\text { and low. The result of this research is that C1 (highest) is } 14 \text { Harvest Block } \\
\text { data, and C2 (lowest) is } 11 \text { Harvest Block data. }\end{array}$ \\
\hline
\end{tabular}

\begin{tabular}{|c|c|}
\hline Kata Kunci & ABSTRAK \\
\hline $\begin{array}{l}\text { Pengelompokan, } \\
\text { Data Mining, } \\
\text { Cluster, } \\
\text { Algoritma K-Means, } \\
\text { Kelapa Sawit, }\end{array}$ & $\begin{array}{l}\text { Berdasarkan data hasil produksi buah sawit di PTPN IV Marihat } \\
\text { menampilkan beberapa Lokasi dengan hasil panen buah yang bervariasi } \\
\text { jumlahnya. Untuk itu diperlukan pengelompokan lokasi potensial penghasil } \\
\text { buah untuk mengetahuni lokasi mana saja yang menghasilkan buah sawit } \\
\text { dengan jumlah banyak ataupun sedikit. Pembagian hasil produksi biasanya } \\
\text { dilakukan berdasarkan loaksi atau blok panen buah kelapa sawit. Oleh karena } \\
\text { itu, dibutuhkan metode untuk memudahkan dalam pengelompokan lokasi } \\
\text { penghasil buah. Dengan pendekatan pengklasteran } K \text {-Means, pembagian } \\
\text { kelompok lokasi dapat dilakukan berdasarkan luas panen (Ha), realisasi } \\
\text { produksi (kg) dan tahun panen. Pada penelitian ini dilakukan pengklasteran } \\
\text { daerah potensial penghasil buah menggunakan algoritma K-Means. Dengan } \\
\text { menggunakan K-Means bertujuan dalam memudahkan pengelompokan suatu } \\
\text { blok dengan hasil produksi buah banyak, dan rendah. Hasil dari penelitian ini } \\
\text { didapakan C1 (tertinggi) ialah } 14 \text { data Blok Panen, dan C2 (terendah) ialah } 11 \\
\text { data Blok Panen. }\end{array}$ \\
\hline
\end{tabular}

\section{Korespondensi Penulis:}

Deny Franata Pasaribu,

STIKOM Tunas Bangsa,

Jalan Sudirman Blok A Nomor 1, 2, 3 Pematangsiantar

Telepon: +62 85155011979

Email: denyfranata2016@gmail.com

\section{PENDAHULUAN}

Kelapa sawit (Elaeis guineensis Jacq) merupakan tanaman tahunan golongan palma yang dapat tumbuh didaerah tropis. Tanaman kelapa sawit berasal dari Nigeria, Afrika Barat. Saat ini perkebunan kelapa sawit menjadi bagian yang sangat penting dari rantai suplai minyak kelapa sawit global dan ada sekitar tiga juta petani perkebunan 
kelapa sawit rakyat di seluruh dunia yang memproduksi sekitar 4 juta ton minyak kelapa sawit. Tanaman kelapa sawit merupakan salah satu penghasil minyak tertinggi per hektar.

PT. Perkebunan Nusantara IV (PTPN IV) merupakan Perusahaan yang bergerak dibidang perkebunan kelapa sawit. Namun dalam pengelolaannya sering kali terjadi penurunan hasil minyak sawit dan inti sawit. Hal ini terjadi karena Belum dilakukan Pemetaan terhadap lokasi buah yang berpotensi baik untuk di produksi oleh pihak terkait dikarenakan terlalu luasnya daerah perkebunan kelapa sawit yang ada pada wilayah Marihat, kemudian pihak terkait masih belum dapat memberikan planning untuk melakukan panen buah berdasarkan blok mana yang lebih berpotensi dengan buah yang baik.

Teknologi pemetaan merupakan teknik membuat data-data di lapangan menjadi sebuah data analisis hasil pengelompokan yang dapat memudahkan pengguna untuk mengetahui sebuah posisi atau letak suatu tempat. Dari permasalahan tersebut penulis ingin melakukan penelitian yang dapat mengetahui lokasi buah kelapa sawit yang berpotensi baik berdasarkan data hasil panen. Data mining adalah teknik pengolahan yang penulis pilih untuk meneliti permasalahan tersebut. Data mining adalah suatu bidang ilmu yang dapat menghasilkan sebuah informasi melalui perhitungan dari data-data lama yang sudah tidak digunakan. Data mining adalah campuran dari statistic, kecerdasan buatan, dan riset basis data yang masih berkembang [1]. Penelitian ini menggunakan Data mining algoritma $K$-Means dalam mengelompokkan lokasi buah kelapa sawit yang berpotensi di PT. Perkebunan Nusantara IV. Algoritma $K$ Means merupakan salah satu metode pengelompokan data non-hierarki yang mempartisi data yang ada ke dalam bentuk dua atau lebih kelompok [2].

Berdasarkan latar belakang yang sudah dijelaskan sebelumnnya maka perumusan masalahnya adalah bagaimana menerapkan proses pengelompokan data hasil produksi sawit dengan algoritma K-Means untuk mengetahui lokasi penghasil buah yang berpotensi, yang berguna bagi pihak PTPN IV Marihat.

Adapun konstrirbusi riset dalam memetakan potensi hasil produksi kelapa sawit ini adalah untuk memberikan tingkat pengamanan pada lokasi yang berpotensi tinggi, sehingga tidak terjadinya pencurian buah serta pihak perkebunan dapat memberi perawatan lebih terhadap tanaman sawit yang berpotensi tinggi untuk di produksi.

Beberapa penelitian yang terkait dengan penelitian ini dapat dilihat pada tabel 1 berikut ini:

\begin{tabular}{|c|c|c|c|}
\hline No & Nama Author & Judul Riset & Hasil Penelitian \\
\hline 1 & $\begin{array}{l}\text { Lailan Azmi, } \\
\text { Mesran dan } \\
\text { Kurnia Ulfa }\end{array}$ & $\begin{array}{l}\text { Prediksi Replanting Lahan Kelapa } \\
\text { Sawit Dengan } \\
\text { Menggunakan Metode K-Nearest } \\
\text { Neighbor } \\
\text { Pada Ptpn Iv Adolina [3]. }\end{array}$ & $\begin{array}{l}\text { Algoritma K-Nearest Neighbor (KNN) dapat } \\
\text { digunakan dalam menentukan lahan kelapa } \\
\text { sawit } \\
\text { yang akan diremajakan pada PTPN IV Adolina. }\end{array}$ \\
\hline 2 & Nenci Sirait & $\begin{array}{l}\text { Implementasi K-Means Clustering } \\
\text { Pada } \\
\text { Pengelompokan Mutu Biji Sawit } \\
\text { (Studi kasus: Pt. Multimas Nabati } \\
\text { Asahan) [4]. }\end{array}$ & $\begin{array}{l}\text { Data mining pengelompokan mutu biji sawit di } \\
\text { PT. } \\
\text { Multimas Nabati Asahan menggunakan metode } \\
\text { K-means Clustering di mulai dari tingkat } \\
\text { kematangan buah sawit berdasarkan standar } \\
\text { mutunya. }\end{array}$ \\
\hline 3 & $\begin{array}{l}\text { Nobertus } \\
\text { Krisandi, } \\
\text { Helmi dan } \\
\text { Bayu Prihandono }\end{array}$ & $\begin{array}{l}\text { Algoritma K-Nearest Neighbor Dalam } \\
\text { Klasifikasi Data Hasil } \\
\text { Produksi Kelapa Sawit Pada Pt. } \\
\text { Minamas } \\
\text { Kecamatan Parindu [5]. }\end{array}$ & $\begin{array}{l}\text { Berdasarkan hasil penelitian, data } \\
\text { diklasifikasikan ke dalam } 6 \text { cluster. Algoritma } k \text { - } \\
\text { NN dapat digunakan dalam klasifikasi data Hasil } \\
\text { Produksi Kelapa Sawit pada PT. Minamas Kec. } \\
\text { Parindu. }\end{array}$ \\
\hline
\end{tabular}

\section{METODE PENELITIAN}

\subsection{Data Mining}

Data Mining merupakan proses kegiatan untuk mengumpulkan data dalam jumlah yang besar untuk menemukan pengetahuan sehingga dapat menjadi informasi yang dapat digunakan [6]. Data mining adalah proses menggunakan teknik statistik, matematika, kecerdasan buatan, dan machine learning untuk mengetahui informasi yang bermanfaat yang terkait dari database yang besar. Tujuan utama Data mining adalah untuk menemukan, menggali, atau menambang pengetahuan dari data atau informasi yang kita miliki.

\subsection{Clustering}

Clustering merupakan proses partisi sekumpulan objek data dari satu set menjadi beberapa kelas. Hal ini dapat dilakukan dengan menerapkan berbagai persamaan dan langkah-langkah mengenai jarak algoritma yaitu dengan Euclidean Distance. Analisis kluster ialah metode yang dipakai untuk membagi rangkaian data menjadi beberapa grup berdasarkan kesamaan-kesamaan yang telah ditentukan sebelumnya. Dalam menentukan cluster berdasarkan data yang telah tersedia dibutuhkan sebuah flowchart untuk memudahkan dalam menentukan alur perhitungan sebagai alur untuk menemukan hasil dari penerapan cluster terhadap data yang akan diproses [7]. 
Clustering adalah metode penganalisaan data yang sering dimasukkan sebagai salah satu metode Data mining yang tujuannya adalah untuk mengelompokkan data dengan karakteristik yang sama. Cluster berbeda dari klasifikasi karena cluster tidak memiliki variabel target. Tujuan cluster bukan untuk mengklasifikasikan, memperkirakan, atau memprediksi nilai variabel taget [8].

\subsection{Algoritma K-Means Clustering}

Algoritma K-Means merupakan algoritma pengelompokan iteratif yang melakukan partisi set data ke dalam sejumlah $K$ cluster yang sudah ditetapkan di awal [9].

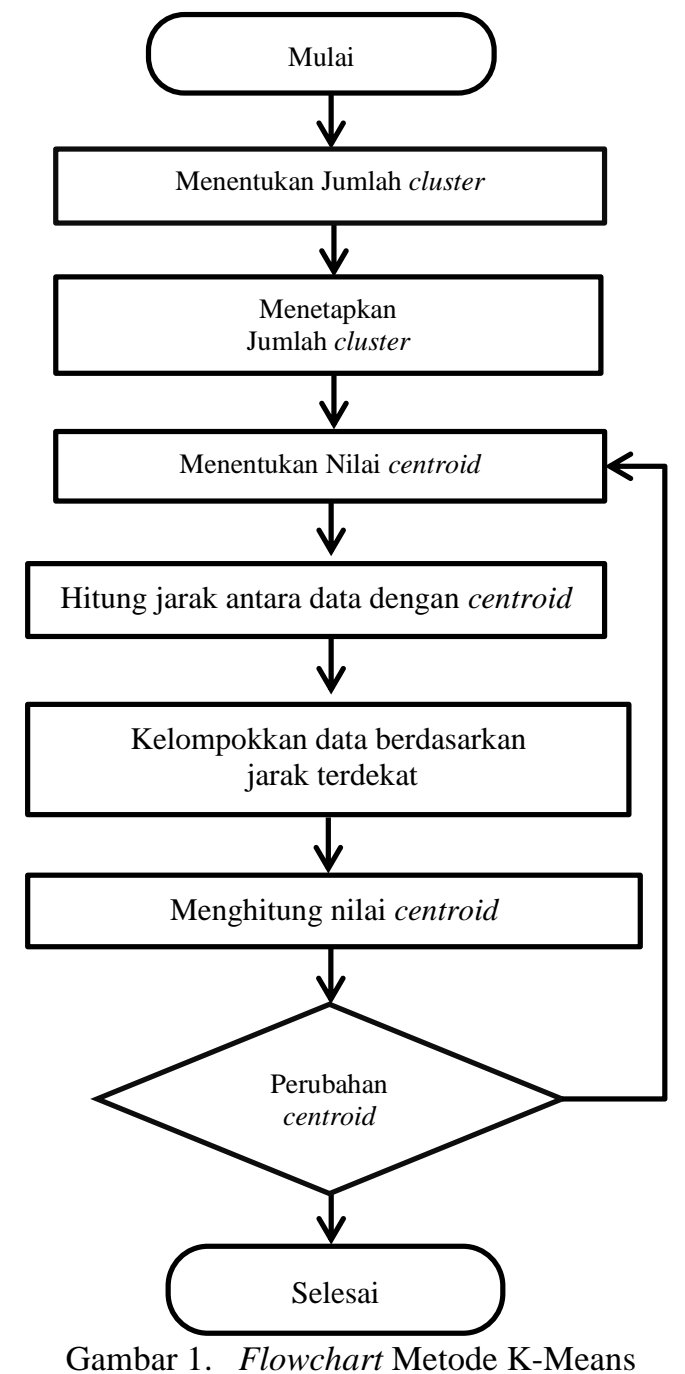

Berikut adalah langkah-langkah penyelesaian yang dilakukan penulis dalam menggelompokkan Hasil Produksi buah sawit yang Produktif menggunakan algoritma K-Means :

1. Menentukan jumlah data yang akan di cluster, dimana sampel data Hasil Produksi yang akan digunakan dalam proses clustering adalah Hasil Panen yang paling Produktif.

2. Menetapkan nilai k jumlah cluster sebanyak 2 cluster (k-2).

3. Menentukan nilai centroid (pusat cluster) awal yang ditentukan secara random berdasarkan nilai variabel data yang di cluster sebanyak nilai k yang ditentukan sebelumnya.

4. Menghitung jarak setiap data yang Produktif terhadap pusat cluster.

5. Menentukan posisi cluster masing-masing data hasil produksi yang produktif berdasarkan jarak minimum data terhadap pusat cluster.

6. Menghitung nilai centroid hasil iterasi dengan Memeriksa kondisi berhenti proses iterasi, jika nilai centroid hasil iterasi dengan nilai centroid sebelumnya bernilai sama atau nilai centroid sudah optimal serta posisi cluster data hasil produksi sawit yang produktif tidak mengalami perubahan lagi maka proses iterasi berhenti. Namun jika nilai centroid tidak sama atau belum optimal serta posisi data hasil produksi buah sawit produktif masih berubah maka proses iterasi berlanjut pada iterasi berikutnya 


\subsection{RapidMiner}

Rapidminer adalah platform perangkat ilmu data yang dikembangkan oleh perusahaan bernama sama dengan yang menyediakan lingkungan terintegrasi untuk persiapan data pembelajaran mesin pembelajaran dalam pengembangan teks dan analisis prediktif.

\subsection{Rancangan Penelitian}

Rancangan penelitian ini pertama kali penulis melakukan pengamatan selanjutnya mengumpulkan data setelah itu data tersebut dipindahkan ke exel (xls) setelah itu data akan diolah melalui proses perhitungan dan mengikuti langkah-langkah proses perhitungan metode k-means Selanjutnya hasil perhitungan tersebut akan diaplikasikan ke RapidMiner untuk melihat keakuratan hasil yang diperoleh.Flowchart Rancangan Penelitian dapat dilihat pada gambar 2 .

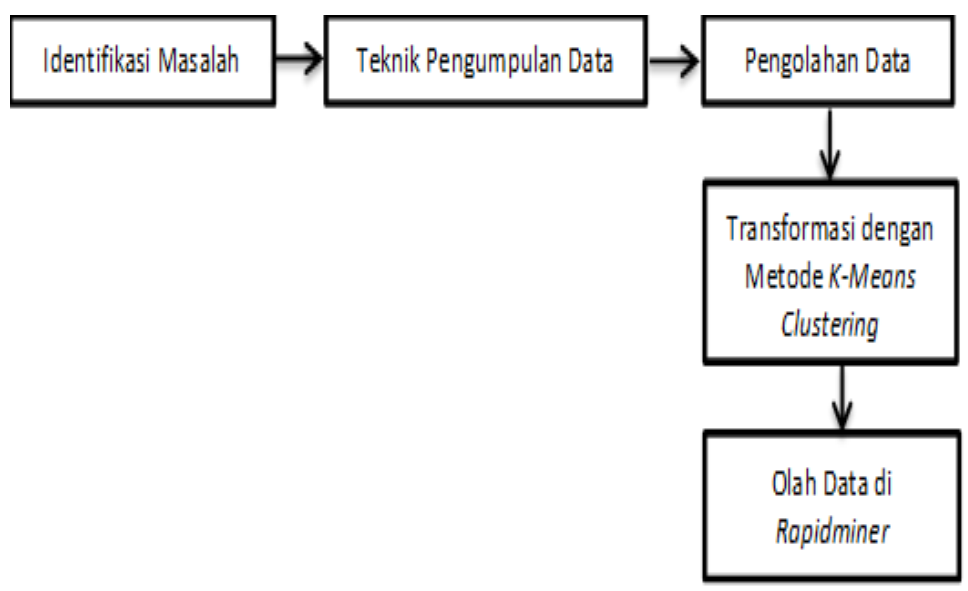

Gambar 2. Rancangan Penelitian

Berikut penjelasan dari alur rancangan penelitan pada gambar 2:

1. Identifikasi Masalah

Merupakan suatu tahap permulaan dari penguasaan masalah dimana suatu objek tertentu dalam situasi tertentu dapat dikenali sebagai suatu masalah. Permasalahan dalam penelitian ini adalah kurangnya pemetaan terhadap blok yang merupakan penghhasil panen sawit yang produktif

2. Teknik Pengumpulan Data

Pengumpulan data dilakukan dengan cara mencari data Hasil Produksi sawit berdasarkan tahun. Untuk data set pertama penulis mengambil data dari PTPN IV Marihat yang mana data Hasil Produksi sawit dari tahun 2015 $-2019$.

3. Pengolahan Data

Pada tahap pengolahan data, data diolah untuk mendapatkan hasil yang kemudian dapat berguna dalam pengambilan keputusan. Data diolah sehingga menjadi informasi. Data yang didapat dalam bentuk file excel sehingga berekstensi .xlsx.

4. Transformasi dengan Metode K-Means Clustering

Transformasi data, data yang tersusun dari urutan blok seperti blok A21, A22, A23, A24 dan A25 harus dilakukan proses inisialisasi data terlebih dahulu ke dalam bentuk angka/numerikal. Kemudian mengelompokkan data yang sudah ada dalam tiga kelompok yaitu banyak, sedang, rendah dengan metode $K$ Means Clustering.

5. Olah Data di Rapidminer

Rapidminer merupakan salah satu software pilihan untuk melakukan ekstraksi data dengan metode-metode data mining. Pengujian disini kita menggunakan sebuah software Rapidminer, dengan pengujian data menggunakan software kita akan membandingkan bagaimana hasil pengolahan data secara manual dengan hasil pengolahan data menggunakan sebuah software.

\subsection{Analisa Data}

Proses analisis data dapat dilakukan setelah adanya pengumpulan data dan setelah data dikumpulkan dan diolah ke excel. Setelah hasil yang telah dapat di excel akan diaplikasikan ke RapidMiner untuk menyesuakian hasil yang didapatkan. Penulis akan melakukan analisa data statistik deskriptif. Data deskriptif adalah metode-metode yang berkaitan dengan pengumpulan data penyajian suatu gugus data sehingga memberikan informasi yang berguna informasi yang dapat diperoleh dari statistika deskriptif ini. Jenis data yang digunakan dalam penelitian ini merupakan 
data sekunder, Data sekunder adalah data yang diperoleh tidak dari sumbernya langsung melainkan sudah dikumpulkan oleh pihak lain dan sudah di olah serta memiliki keterkaitan dengan permasalahan yang di teliti.

\subsection{Alat Analisa Data}

Dalam melakukan penelitian ini penulis menggunakan Microsoft excel dan RapidMiner sebagai alat untuk memproses data, Microsoft Excel digunakan untuk membantu dalam proses perhitungan yang akan dilakukan setelah proses perhitungan selesai maka selanjutnya diaplikasikan ke RapidMiner untuk melihat keakuratan hasil yang didapat dari perhitungan di excel serta akan dicocokan dengan hasil yang sudah diaplikasikan ke RapidMiner tersebut.

\section{HASIL DAN ANALISIS}

\subsection{Pengolahan Data}

Penelitian ini menggunakan Data Mining metode $K$-Means, Pada tahapan ini dilakukan analisis data hasil Produksi Kelapa sawit berdasarkan blok masing-masing dengan tool RapidMiner. RapidMiner adalah sebuah software pilihan untuk melakukan ekstraksi data dengan metode-metode Data Mining. Berikut adalah data hasil produksi kelapa sawit yang diambil dari PTPN IV Marihat.

Berikut adalah data hasil Produksi Kelapa sawit yang diambil penulis langsung dari PTPN IV Marihat :

Tabel 2. Data Hasil Produksi Kelapa Sawit

\begin{tabular}{|c|c|c|c|c|}
\hline \multirow{2}{*}{ Blok Panen } & \multirow{2}{*}{ Tahun } & \multirow{2}{*}{$\frac{\text { Luas Areal }}{(\mathrm{Ha})}$} & \multirow{2}{*}{$\frac{\text { Berat Janjang }}{(\mathrm{Kg})}$} & \multirow{2}{*}{$\frac{\text { Realisasi Produksi }}{(\mathrm{Kg})}$} \\
\hline & & & & \\
\hline A 21 & \multirow{5}{*}{2015} & 34,35 & 8,1 & 14720 \\
\hline A22 & & 22,65 & 7,5 & 10760 \\
\hline A23 & & 31,56 & 8,7 & 19350 \\
\hline A24 & & 32,19 & 8,4 & 16720 \\
\hline A 25 & & 33,12 & 8,2 & 15100 \\
\hline $\mathrm{A} 21$ & \multirow{5}{*}{2016} & 34,35 & 8,1 & 14520 \\
\hline A22 & & 22,65 & 7,5 & 10260 \\
\hline A 23 & & 31,56 & 8,7 & 19150 \\
\hline A24 & & 32,19 & 8,4 & 16220 \\
\hline A25 & & 33,12 & 8,2 & 14900 \\
\hline $\mathrm{A} 21$ & \multirow{5}{*}{2017} & 34,35 & 8,1 & 14620 \\
\hline A22 & & 22,65 & 7,5 & 10790 \\
\hline $\mathrm{A} 23$ & & 31,56 & 8,7 & 19990 \\
\hline A 24 & & 32,19 & 8,4 & 16810 \\
\hline A25 & & 33,12 & 8,2 & 15300 \\
\hline A21 & \multirow{5}{*}{2018} & 34,35 & 8,1 & 14780 \\
\hline A22 & & 22,65 & 7,5 & 10800 \\
\hline A 23 & & 31,56 & 8,7 & 19850 \\
\hline A24 & & 32,19 & 8,4 & 16620 \\
\hline A25 & & 33,12 & 8,2 & 15230 \\
\hline A21 & \multirow{5}{*}{2019} & 34,35 & 8,1 & 14770 \\
\hline A22 & & 22,65 & 7,5 & 10860 \\
\hline A 23 & & 31,56 & 8,7 & 19890 \\
\hline A24 & & 32,19 & 8,4 & 16560 \\
\hline A25 & & 33,12 & 8,2 & 15380 \\
\hline
\end{tabular}

Langkah- Langkah perhitungan metode $K$-Means Clustering:

1. Menentukan Jumlah cluster dan Centorid

Data tersebut akan masuk ke tahapan clustering dengan menerapkan algoritma $K$-Means menggunakan RapidMiner untuk mengcluster data menjadi dua cluster. Data yang sudah dipilih akan dimasukkan kedalam tool RapidMiner. Kemudian Dalam penerapan algoritma K-Means dihasilkan nilai titik tengah atau centroid dari data yang didapat dengan ketentuan bahwa clusterisasi yang diinginkan adalah 2, penentuan cluster dibagi atas 2 bagian 
yakni cluster tingkat tinggi (C1), cluster tingkat rendah (C2). Penentuan titik cluster ini dilakukan dengan mengambil nilai terbesar (maksimum) untuk cluster tingkat tinggi (C1), nilai terkecil (minimum) untuk cluster tingkat rendah $(\mathrm{C} 2)$.

Untuk mendapatkan nilai tertinggi dan terendah (C1) dan (C2) dari data tabel yang ada maka kita harus mengambil nilai berdasarkan atribut nya masing masing. Untuk Luas Areal yang terbesar (C1) adalah 34,35 Ha sedangkan yang terendah (C2) adalah 22,65 Ha. Kemudian Untuk Berat Janjang yang terbesar (C1) adalah 8,7 Kg sedangkan yang terendah (C2) adalah 7,5 Kg. Kemudian Untuk Realisasai Produksi yang terbesar (C1) adalah $19990 \mathrm{Kg}$ sedangkan yang terendah (C2) adalah $10260 \mathrm{Kg}$. Sehingga di dapat nilai untuk C1 dan C2 seperti tabel berikut.

Tabel 3. Nilai Centroid

\begin{tabular}{llll} 
C1 & 34,35 & 8,7 & 19990 \\
\hline C2 & 22,65 & 7,5 & 10260 \\
\hline
\end{tabular}

2. Menghitung Jarak dari Centorid

Untuk menghitung jarak antara titik Centroid dengan titik tiap objek menggunakan Euclidean Distance. Rumus untuk menghitung jarak dari Centroid adalah:

$$
\mathrm{De}=\sqrt{(x i-s i)^{2}+(y i-t i)^{2}}
$$

Maka perhitungan untuk jarak dari Centroid ke-1 adalah sebagai berikut :

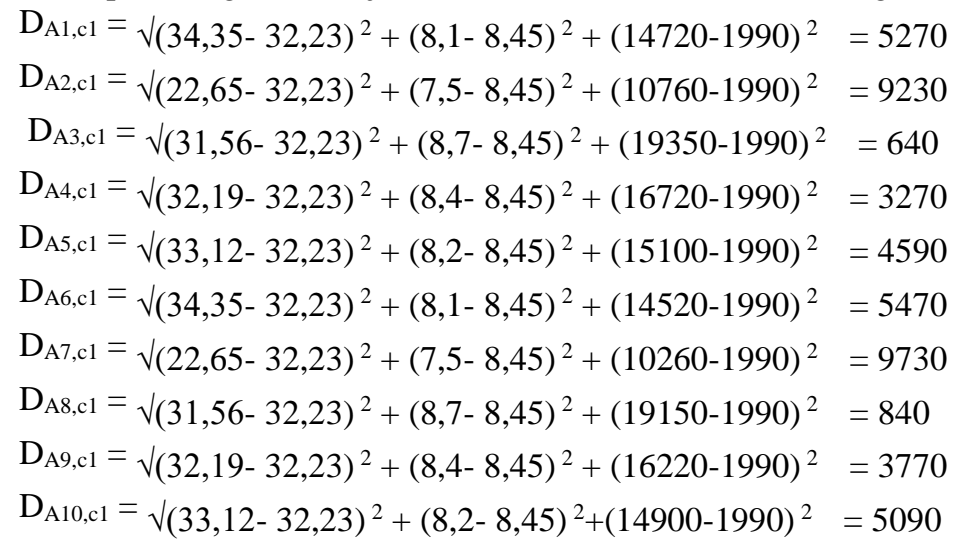

Selanjutnya perhitungan untuk jarak dari Centroid ke-2 adalah sebagai berikut:

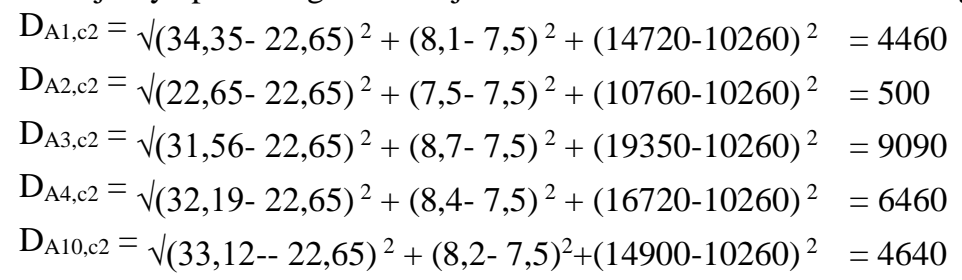

sehingga didapat tabel jarak dari Centroid dan mencari nilai minimal dari kedua centroid. Tabel jarak dari centroid adalah sebagai berikut :

Tabel 4. Nilai Iterasi Ke 1

\begin{tabular}{lllll}
\multicolumn{1}{c}{ C1 } & \multicolumn{1}{c}{ C2 } & $\begin{array}{c}\text { JARAK } \\
\text { TERPENDEK }\end{array}$ & C1 & C2 \\
\hline 5270,000034 & 4460,015387 & 4460,015387 & & 1 \\
9230,007493 & 500 & 500 & & 1 \\
640,0060813 & 9090,004446 & 640,0060813 & 1 & \\
3270,000727 & 6460,007107 & 3270,000727 & 1 & \\
4890,00018 & 4840,011375 & 4840,011375 & 1 & \\
5470,000033 & 4260,016109 & 4260,016109 & & 1 \\
9730,007108 & 0 & 0 & & 1 \\
840,0046334 & 8890,004546 & 840,0046334 & 1 & \\
3770,000631 & 5960,007703 & 3770,000631 & 1 & \\
5090,000173 & 4640,011865 & 4640,011865 & & 1 \\
5370,000034 & 4360,01574 & 4360,01574 & & 1 \\
9200,007518 & 530 & 530 & & 1 \\
2,79 & 9730,004154 & 2,79 & 1 &
\end{tabular}




\begin{tabular}{lllll}
3180,000748 & 6550,007009 & 3180,000748 & 1 & \\
4690,000188 & 5040,010924 & 4690,000188 & 1 & \\
\hline 5210,000035 & 4520,015182 & 4520,015182 & & 1 \\
9190,007526 & 540 & 540 & & 1 \\
140,0277976 & 9590,004214 & 140,0277976 & 1 & \\
3370,000706 & 6360,007219 & 3370,000706 & 1 & \\
4760,000185 & 4970,011078 & 4760,000185 & 1 & \\
\hline 5220,000034 & 4510,015216 & 4510,015216 & & 1 \\
\hline 9130,007576 & 600 & 600 & & 1 \\
100,0389129 & 9630,004197 & 100,0389129 & 1 & \\
3430,000693 & 6300,007287 & 3430,000693 & 1 & \\
4610,000191 & 5120,010753 & 4610,000191 & 1 & \\
\hline
\end{tabular}

3. Menentukan Cluster atau Pengelompokan

Dalam menentukan Cluster dengan nilai Cluster berdasarkan nilai yang sama dari nilai Cluster dan diletakkan pada Cluster yang sesuai dengan nilai sama pada Iterasi 1 . Selanjutnya dalam metode $K$-Means, perhitungan berhenti apabila Cluster pada iterasi yang dihasilkan sama pada iterasi sebelumnya. Maka selanjutnya mencari Cluster pada iterasi selanjutnya sampai nilai iterasinya sama. Untuk mencari nilai Centroid selanjutnya dengan menggunakan Centroid baru pada Iterasi ke-1 dengan menjumlahkan nilai sesuai yang tertera pada Cluster di tabel diatas. Adapun Centroid baru untuk mencari Cluster selanjutnya adalah dengan menjumlahkan nilai yang terpilih pada Cluster tersebut kemudian membagikannya sebanyak jumlah nilai sebagai berikut :

$C_{1 a}=(31,56+32,19+33,12+31,56+32,19+31,56+32,19+33,12+31,56+32,19+33,12+31,56+32,19$ $+33,12) / 14=32,230$

$C_{1 b}=(8,7+8,4+8,2+8,7+8,4+8,7+8,4+8,2+8,7+8,4+8,2+8,7+8,4+8,2) / 14=8,45$

$C_{1 c}=(19350+16720+15100+19150+16220+19990+16810+15300+19850+16620+15230+19890+$ $16560+15380) / 14=17297,857$

Maka, data Centroid baru Iterasi ke-1 adalah sebagai berikut :

Tabel 5. Centroid Baru

\begin{tabular}{cccc} 
C1 & 32,23071429 & 8,45 & 17297,85714 \\
\hline C2 & 28,92 & 7,836363636 & 12889,09091 \\
\hline
\end{tabular}

Sehingga didapat tabel jarak dari Centroid dan mencari nilai minimal dari kedua centroid. Tabel jarak dari centroid adalah sebagai berikut :

Tabel 6. Nilai Iterasi Ke 2

\begin{tabular}{|c|c|c|c|c|}
\hline $\mathrm{C} 1$ & $\mathrm{C} 2$ & $\begin{array}{c}\text { JARAK } \\
\text { TERPENDEK }\end{array}$ & C1 & $\mathrm{C} 2$ \\
\hline 2577,858038 & 1830,917162 & 1830,917162 & & 1 \\
\hline 6537,864232 & 2129,100168 & 2129,100168 & & 1 \\
\hline 2052,142982 & 6460,909688 & 2052,142982 & 1 & \\
\hline 577,8571465 & 3830,910528 & 577,8571465 & 1 & \\
\hline 2197,857337 & 2210,91311 & 2197,857337 & 1 & \\
\hline 2777,857973 & 1630,918152 & 1630,918152 & & 1 \\
\hline $\mathrm{C} 1$ & $\mathrm{C} 2$ & $\begin{array}{c}\text { JARAK } \\
\text { TERPENDEK }\end{array}$ & C1 & $\mathrm{C} 2$ \\
\hline 7037,863728 & 2629,098407 & 2629,098407 & & 1 \\
\hline 1852,142995 & 6260,909707 & 1852,142995 & 1 & \\
\hline 1077,857145 & 3330,910744 & 1077,857145 & 1 & \\
\hline 2397,857321 & 2010,91351 & 2010,91351 & & 1 \\
\hline 2677,858004 & 1730,917628 & 1730,917628 & & 1 \\
\hline 6507,864264 & 2099,1003 & 2099,1003 & & 1 \\
\hline 2692,142952 & 7100,909634 & 2692,142952 & 1 & \\
\hline 487,8571471 & 3920,910495 & 487,8571471 & 1 & \\
\hline 1997,857356 & 2410,912777 & 1997,857356 & 1 & \\
\hline 2517,858059 & 1890,916906 & 1890,916906 & & 1 \\
\hline 6497,864275 & 2089,100345 & 2089,100345 & & 1 \\
\hline 2552,142958 & 6960,909645 & 2552,142958 & 1 & \\
\hline 677,8571459 & 3730,910566 & 677,8571459 & 1 & \\
\hline
\end{tabular}




\begin{tabular}{llllll}
2067,857349 & 2340,912887 & 2067,857349 & 1 & \\
2527,858055 & 1880,916947 & 1880,916947 & & 1 \\
6437,864342 & 2029,100624 & 2029,100624 & & 1 \\
2592,142956 & 7000,909642 & 2592,142956 & 1 & \\
737,8571457 & 3670,910591 & 737,8571457 & 1 & \\
1917,857365 & 2490,912658 & 1917,857365 & 1 & \\
\hline
\end{tabular}

Dari tabel Cluster Iterasi ke-1 dan tabel Cluster Iterasi ke-2 memiliki nilai Cluster yang sama atau tidak berubah pada cluster terakhir maka perhitungan dihentikan dan hasil yang diperoleh yaitu:

1. Cluster 1 (Cl) mendapatkan 14 data Blok Panen dalam artian bahwa kelompok pertama termasuk kategori Hasil panen tertinggi Pada Tahun 2015 - 2019.

2. Cluster 2 (C2) mendapatkan 11 Blok dalam artian bahwa kelompok kedua termasuk kategori hasil panen rendah pada tahun 2015-2019.

Dari tabel Cluster Iterasi ke-1 dan tabel Cluster Iterasi ke-2 memiliki nilai Cluster yang sama atau tidak berubah pada cluster terakhir maka perhitungan dihentikan.

\subsection{Pemodelan RapidMiner}

Dalam menjalankan proses untuk membentuk pemodelan, tahap pertama yang dilakukan adalah importing data dari data yang sudah di transformasi terlebih dahulu ke dalam Microsoft Excel dengan format .xls agar dapat diakses menggunakan software RapidMiner. Atribut yang digunakan sebagai label adalah data hasil panen jagung. Dalam melakukan importing data, dibutuhkan operator baru seperti gambar berikut.

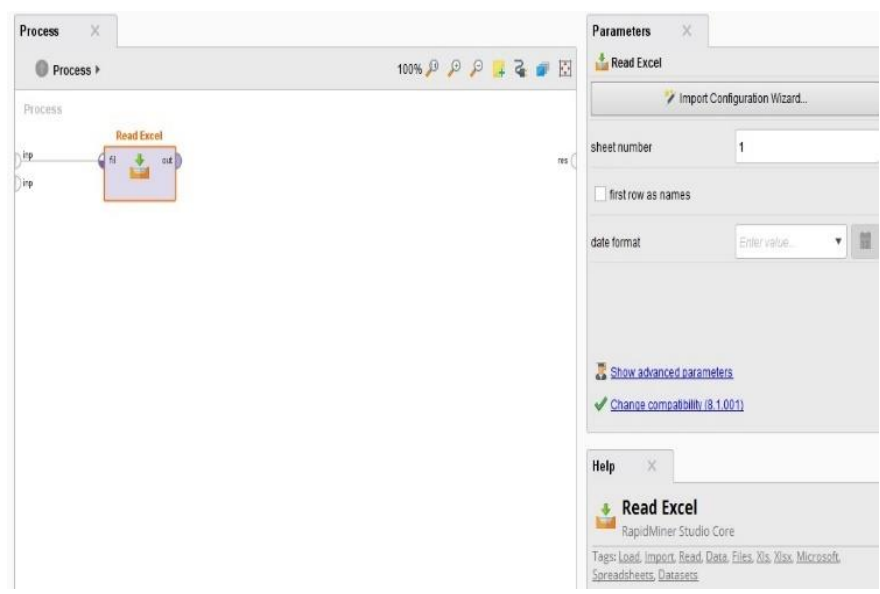

Gambar 3. New Process Untuk Import Data Excel

Pilih data yang akan digunakan untuk di import. Lakukan drag and drop data yang dipilih kedalam main process. Berikut alur proses import data yang dilakukan. Pada import data wizard step 1, pilih data berformat .xls pada folder yang akan di import.

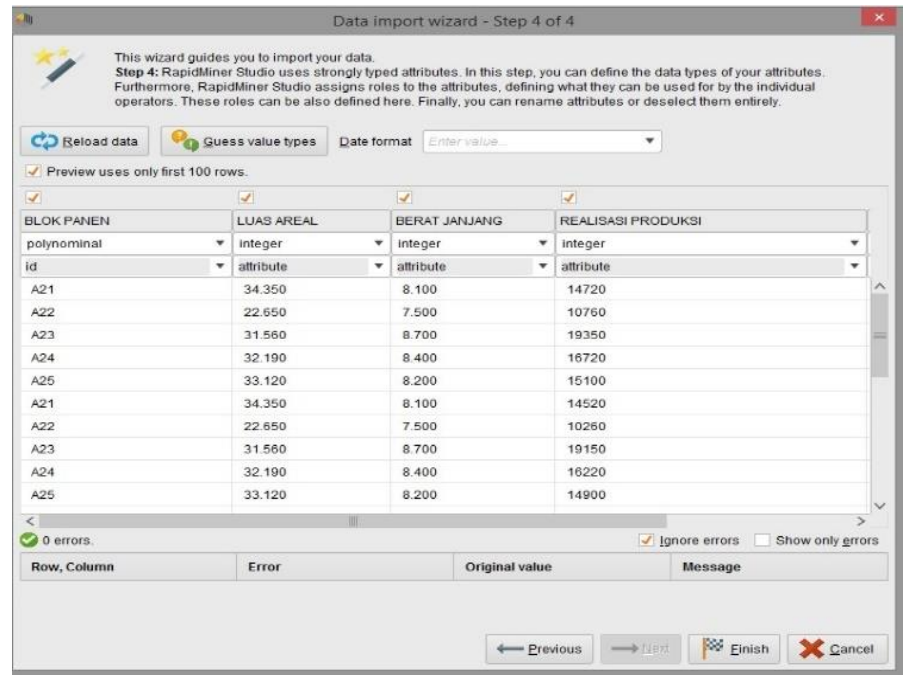

Gambar 4. Alur Proses Import Data Step 2 
Pada data import wizard step 2, data sawit.xls dengan import excel dimasukan. File Excel dapat berisi beberapa lembar, cukup menandai beberapa sel yang akan dimuat. Pada proses kali ini, peneliti memilih sel 1 untuk dilanjutkan prosesnya kemudian klik next. Langkah berikutnya drag dan drop operator $K$-Means lalu hubungkan pada output.

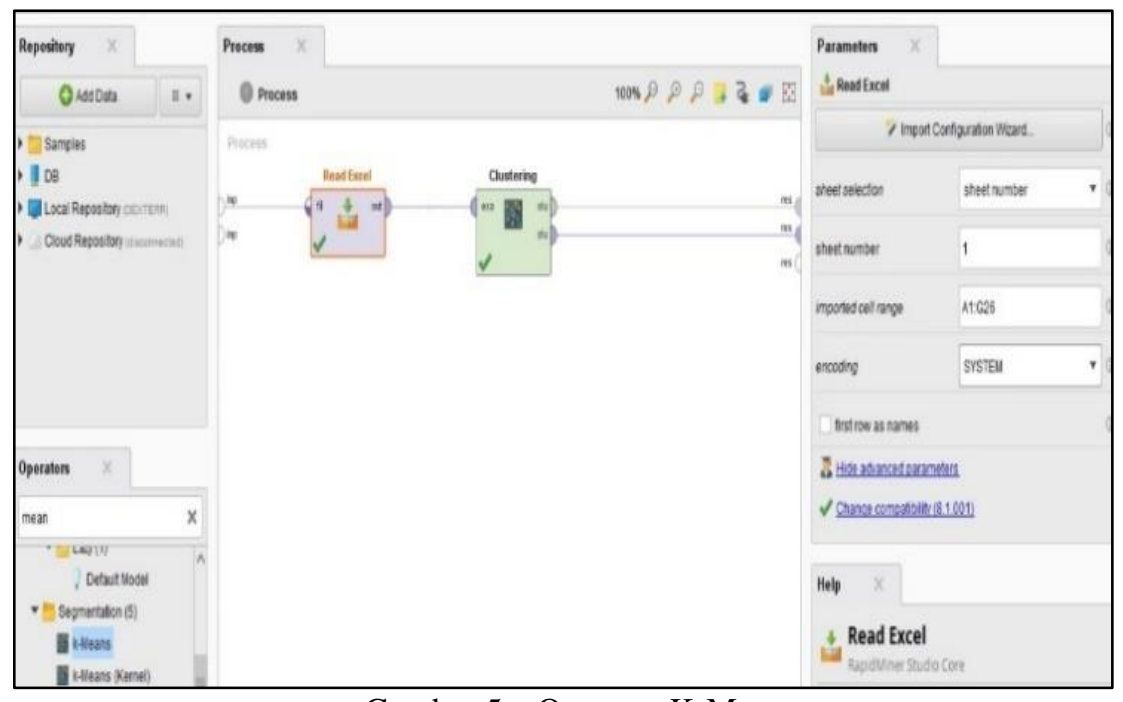

Gambar 5. Operator K-Means

Pada saat tool run diklik akan muncul hasil cluster seperti gambar dibawah.

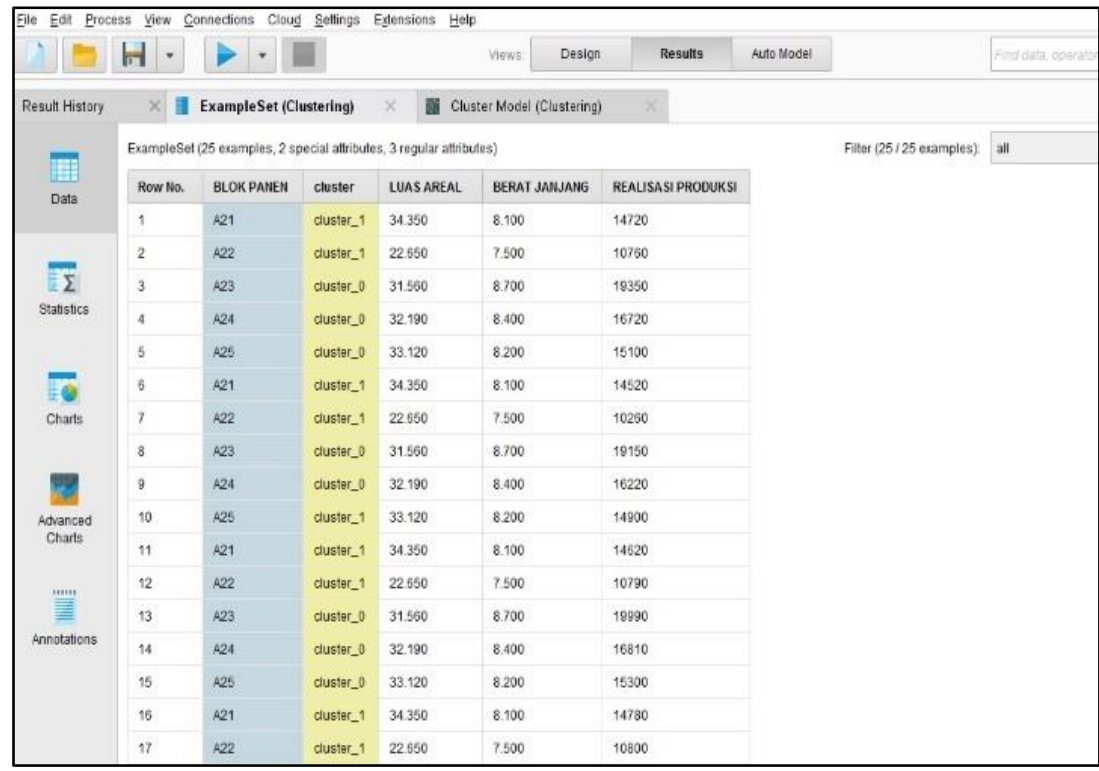

Gambar 6. Data Hasil Clustering 
Dari gambar 6 dapat dilihat bahwa perhitungan manual yang dilakukan memiliki hasil yang sama dengan menggunakan software RapidMiner, dimana dari 25 data hasil produksi kelapa sawit yang diuji hasil yang didapatkan yaitu 14 data termasuk kedalam cluster tertinggi dan 11 data termasuk kedalam cluster terendah. Sehingga berdasarkan data hasil clustering pada gambar 6 didapatkan grafik hasil dari RapidMiner 7 berikut ini:

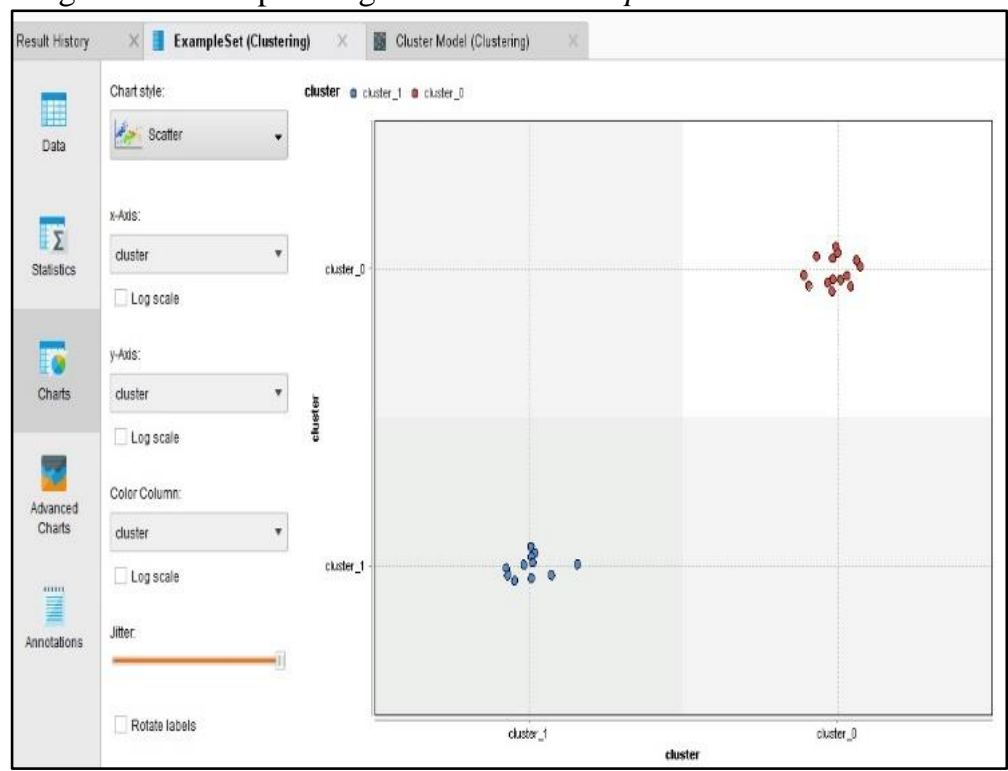

Gambar 7. Grafik Clustering

\section{KESIMPULAN}

Berdasarkan pembahasan sebelumnya dapat disimpulkan bahwa: Metode yang digunakan dalam perhitungan skripsi ini adalah penerapan data mining dengan metode $K$-Means Clustering. Hasil dari penelitian menggunakan metode $K$-Means ini berupa 2 (dua) buah cluster yaitu cluster tinggi dan cluter rendah. Penerapan Algoritma $K$-means dapat diimplementasikan terhadap pemetaan hasil produksi buah sawit. Penerapan Algoritma $K$-means dapat diimplementasikan ke dalam software Rapidminner. Hasil dari penelitian ini di dapakan C1 (tertinggi) ialah 14 data Blok Panen, dan C2 (terendah) ialah 11 data Blok Panen.

\section{UCAPAN TERIMA KASIH}

Dalam melakukan penelitian ini tentu ada dukungan dari banyak pihak mulai dari anggota keluarga, rekan kerja, dosen dan para pegawai di PTPN IV Marihat. Untuk itu kepada semua pihak yang terlibat kami ucapkan terima kasih.

\section{REFERENSI}

[1] Asroni and R. Adrian, "Penerapan Metode K-Means Untuk Clustering Mahasiswa Berdasarkan Nilai Akademik Dengan Weka Interface Studi Kasus Pada Jurusan Teknik Informatika UMM Magelang," vol. 18, no. 1, pp. 76-82, 2016.

[2] A. F. Tanjung, T. M. Diansyah, and Rismayanti, "Pemanfaatan Algortima K-Means Clustering Sebagai Pengamanan Pencurian Buah Kelapa Sawit Se-Distrik Tandun PT . Perkebunan Nusantara V," vol. 3, no. 4, pp. 351-356, 2019.

[3] A. Lailan and U. Kurnia, "Prediksi Replanting Lahan Kelapa Sawit Dengan Menggunakan Metode KNearest Neighbor,” PELITA Inform., vol. 18, pp. 517-522, 2019.

[4] N. Sirait, "Implementasi K-Means Clustering Pada Pengelompokan Mutu Biji Sawit," J. Pelita Inform., vol. 16, no. 4, pp. 368-372, 2017.

[5] N. Krisandi, Helmi, and B. Prihandono, "Algoritma K-Nearest Neighbor Dalam Klasifikasi Data HAsil Produksi Kelapa Sawit Pada PT. Minamas Kecamatan Parindu,” vol. 02, no. 1, pp. 33-38, 2013.

[6] Gustientiedina, M. H. Adiya, and Y. Desnelita, "Penerapan Algoritma K-Means Untuk Clustering Data Obat-Obatan Pada RSUD Pekanbaru," vol. 01, pp. 17-24, 2019.

[7] L. Maulida, "Penerapan Data Mining Dalam Mengelompokkan Kunjungan Wisatawan Ke Objek Wisata Unggulan Di Prov. DKI Jakarta Dengan K-Means,” vol. 2, no. 3, pp. 167-174, 2018.

[8] N. Erlangga, Solikhun, and Irawan, "Penerapan Data Mining Dalam Mengelompokan Produksi Jagung Menurut Provinsi Menggunakan Algoritma K-Means,” vol. 3, pp. 702-709, 2019.

[9] I. Parlina, A. P. Windarto, A. Wanto, and M. R. Lubis, "Memanfaatkan Algoritma K-Means Dalam Menentukan Pegawai Yang Layak Mengikuti Asessment Center Untuk Clustering Program SDP," vol. 3, no. 1, pp. 87-93, 2018. 